\title{
Impact of visual merchandising on the purchase decision of consumers from retail stores in central
} Peru

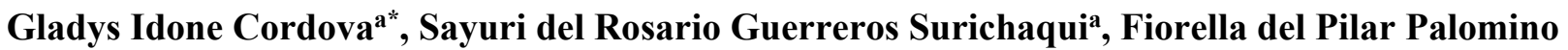 Ricaldi $^{a}$ and Wagner Vicente-Ramos ${ }^{\mathrm{a}}$}

\begin{tabular}{|c|c|}
\hline C H R O N I C L E & A B S T R A C T \\
\hline $\begin{array}{l}\text { Article history: } \\
\text { Received: March 12, } 2020 \\
\text { Received in revised format: } \\
\text { March } 272020 \\
\text { Accepted: March 29, } 2020 \\
\text { Available online: } \\
\text { April 2, } 2020 \\
\text { Keywords: } \\
\text { Visual merchandising } \\
\text { Purchase decision } \\
\text { Organization of the exterior of the } \\
\text { business } \\
\text { Organization of the interior of the } \\
\text { business } \\
\text { Environmental factors of the busi- } \\
\text { ness } \\
\text { Warehouses }\end{array}$ & 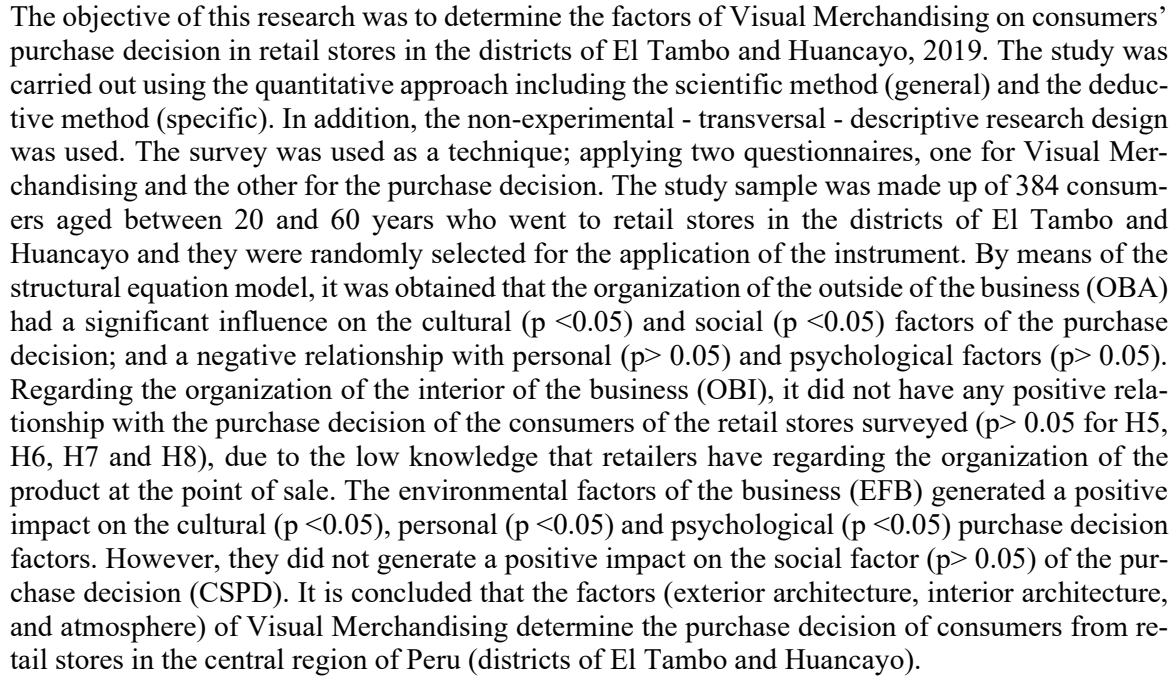 \\
\hline
\end{tabular}

\section{Introduction}

Castillo (2019), president of the Latin American Association of Visual Merchandising and Retail Design, during the 4th Latin American Congress of Visual Merchandising and Retail Design mentioned that Visual Merchandising (VM) is changing continuously, as fast as the consumer, since it is both the "accommodate clothing, furniture or accessories", and is a basis of design and creativity, as well as the senses well on the business. Making the commercial space profitable is, without a doubt, the VM's main challenge; in other words, everything that is placed on the sales floor must be measured. In other words, instore and storefront campaigns must have very clear brand and sales objectives, therefore, working in multidisciplinary teams is essential, since it will guarantee the optimal development of VM in stores. Over the years, the VM has been adapted to changes in the consumer according to their tastes and preferences, as well as to technology, since both are extremely important factors for this strategy, as each day there are more accessible options for facilitating the purchase and sales of products. It

* Corresponding author

E-mail address: gidone@continental.edu.pe (G. Idone Cordova)

(C) 2020 by the authors; licensee Growing Science, Canada doi: $10.5267 /$ j.msl.2020.4.005 
should be noted that transnational companies are the first to implement an exclusive sales format where they include the VM strategy; therefore, it is essential to mention that each commercial space is, without a doubt, a place of sales that helps to make a company profitable. Salazar (2016) states that, in order to maintain profitable relationships with wineries, mass consumption companies must carefully segment the wide variety of establishments they serve to design promotions, exhibitions, discounts, incentives, and sales and distribution approaches. Polling consumers and merchants plays a vital role in the sales force and influences negotiating incentive packages and monitoring performance. However, a typical image in Latin America is the "corner wineries", that is, independent retail stores are located in all neighborhoods, ranging from stalls and kiosks selling soft drinks and sweets, to grocery and product stores basic. These, do not normally pay attention to the strategies at the point of sale.

There are approximately 1 million of these businesses in Brazil, more than 800,000 in Mexico, 400,000 in Colombia, and just over 400,000 in Peru. Despite the inevitable consolidation of growth in large modern supermarkets such as Wong, Plaza Vea, Tottus and Makro, neighborhood wineries will continue to account for a significant share of retail sales in Latin America and other emerging markets. However, every day it is more difficult for mass consumption companies to obtain profits from direct sales to wineries, as competition has increased due to the limited space on the shelves of these stores and the money they invest. Meanwhile, the large chains continue to advance, thereby reducing the sales and profit margins of the wineries. The vast majority of wineries located anywhere in the world and / or sector, are facing a market in which large supermarkets are increasingly positioned, due to the fact that they exert commercial pressure that affects both sales and margins. profit, for the fact of presenting the products in a differentiated way with clearly mapped marketing and sales techniques. However, it is unlikely that wineries tend to disappear, since they are a preferred shopping channel (accessibility and proximity) by consumers and represent a social and economic value for the economy of their environment. Ramírez and Alférez (2014), through a study, demonstrated that Visual Merchandising, among other stimuli, directly affects the purchase decision at the point of sale, since the measures adopted can be changed by up to $61 \%$ of the cases. Buitrago and Perea (2015) developed an investigation in which they demonstrated that an adequate Visual Merchandising allows customers to feel attracted in a rational and emotional way, achieving a satisfactory shopping experience. Shankhwar (2017) conducted a study and reported that there is sufficient evidence that retailers can use visual merchandising to increase product convenience and help customers learn about products and create favorable consumer attitudes. According to Rajesh (2019), retailers should focus on visual advertising methods to attract new customers and increase their permanence in the store, thereby influencing them. Saricam, Okur, Erdem, Akdag and Kilikci (2018) mention that the MV is an effective strategy to strengthen the perception of the image of the store, managing to capture the attention of customers and increasing sales. Consequently, the MV will help retailers increase the number of consumers. On the other hand, in recent years the entrepreneurship of retail stores has undergone a growing phenomenon of expansion throughout Peru, according to information from the National Institute of Statistics and Informatics (INEI). Annually, it is verified that the municipalities have been granting operating licenses for the opening of warehouses. In 2017, 16,474 licenses were assigned to warehouses. Based on INEI (2018) data at the national level, the first three departments that granted the largest number of licenses for wineries were: Lima (33.4\%), Junín (5.3\%) and La Libertad (5.0\%). Due to the increasing number of retail stores on the market, competition is increasing, which is why it is important for retail store owners to bet on new strategies and techniques that capture the attention of consumers. However, many of them do not have the necessary budget to be able to introduce new techniques that influence the purchase decision (Coca Cola Journey, 2017).

The wineries are being seriously affected by the entry and expansion of large chains of convenience stores and specialized minimarkets in retail, which are taking away the market position of the winemaking sector. These large retail chains, such as Plaza Vea and Tottus have a different commercial sales format in which the Visual Merchandising technique stands out, which aims to transmit the image of what the store is and what the store sells, generating a "targeted" customer flow and driving impulse sales; achieving the exhibition of the products in their best visual conditions in terms of persuasion and attraction (Palomares, 2011).

\section{Literary Review}

\subsection{Visual Merchandising}

According to Palomares (2015), merchandising is defined as a conglomerate of marketing techniques, encompassing commercial techniques that allow products to be presented in the right conditions. These techniques developed by retail individuals are a set of activities as old as commerce. Visual or presentation merchandising is a technique with the ability to attract customers through visual exposure. According to Palomares (2015), VM tries to draw the consumer's attention to the merchandise, through the development of plant designs and three-dimensional (3D) screens so that sales are thus maximized, appealing to any strategy that allows the customer to be convinced persuading him to make the purchase. Palomares (2011) mentions that VM is an attractive and attractive technique to present and show products to target and potential consumers, since it seeks to select the right merchandise and place it in the right place, using the allocated space efficiently. Its main objective is to increase sales by capturing the attention of consumers, inviting them to enter and stay in the store, giving them a positive experience and motivating them to make an unplanned and impulsive purchase. According to Ruiz (2018), the MV is a set of techniques and actions that encompass the presentation, placement and arrangement of the product, in addition to the control of the appearance offered to the customer at the point of sale. According to Miquel et al. (2008), Visual Merchandising is focused on clarifying the location of all products, optimizing customer circulation, leading them to visit as many 
sections and facilitate your purchases offering speed and comfort. For Palomares (2015), Visual Merchandising is made up of the following dimensions, exterior architecture, interior architecture, atmosphere, exposure levels, packaging, window dressing, presentation and advertising at the point of sale. The MV is considered a silent seller and a promotional tool, as it is an influential element in marketing communication to the retailer.

\subsubsection{External business organization}

They are the features that are outside the establishment, and reflect the personality and identity of the business; There are three elements (entrance, showcase or showcase and the label) that emit information to attract the customer's attention. The function of the sign or notice is to emphasize the identity of the business through symbols, name and color; having to go according to the line of business, it also generates a positive effect on the customer. The notice or entrance must be placed in a visible place and with bright colors to be identified from afar. The showcase or showcase is the main means that relates to the customer and establishment; the showcase must be persuasive and informative, in order to capture the customer's attention in a short time, it must also provide information on product price, fashion, quality, variety and design. The elements of a showcase, according to Palomares (2015), serve to inform and persuade the consumer, therefore, it is important that customers' lifestyles and customs are taken into account for their design. Due to this, it is essential to adapt the windows according to the product. In the showcases, the merchandise is the most important element for visual attraction, therefore, the products that are exhibited must produce the greatest visual strength, whether due to their color, shape, design or texture. The composition of the windows is another essential element; therefore, the products must be ordered in an aesthetic environment and in harmony to avoid confusing the customer. Likewise, in the assembly of the showcase, diagonal, vertical, horizontal and curved lines must be identified, with the aim of separating each product. Another important factor is light; since the spotlights should not dazzle the client, but concentrate it on specific points of the showcase. Finally, the color must be selected with a lot of criteria, since it causes different reactions and sensations to the consumer, for which the selection of this is very careful.

Another element of the external organization of the business is the entrance; it must reflect the entire interior; therefore, the doors must be made of glass and allow customers to observe the interior. To do this, it must be open, as this will allow easy access. The entrance must not be a barrier; therefore, it must be totally clear.

\subsubsection{Internal business organization}

The organization of the interior of the business is very important, therefore, the products must be located at strategic points, for this, merchants will determine the route that customers will take to locate the products. The determination of the access point to the establishment is an important factor in the design of the business, since it will help clients locate themselves in the establishment. It is recommended that the access point be on the right side or the center of the room to promote circulation in the room. Another important aspect is the location of the hot and cold zone; the hot zone is the closest place to the entrance where the products with the least turnover or those that want to be promoted are located; it is the area where customers transit more frequently, independent of the product they are looking for. The cold zone is located in the area furthest from the store and contains the products with the highest turnover or the highest frequency of purchase, the objective is to direct the consumer to less crowded areas and to observe the entire store. The location of the products in the showcases must also be taken into account, since this allows determining the consumer's purchase decision, therefore, the head of the gondola or showcase is a strategic point for a product to be sold; since, if it is at the correct height of the eyes and in an optimal position for the reach of the hands, there will be a greater possibility that the purchase will be made. Finally, the point of sale, according to Kotler and Armstrong (2017), is the location where the product is presented, and the various benefits of its purchase such as promotions, offers, gifts, among others, these are short-term incentives that help persuade the consumer to purchase the product. The points of sale also reflect the connectivity and the participation between the seller and the client, being key aspects to improve the shopping experience, giving the client all the information about the product and the benefits that it will bring him in case he acquired it. In this way, according to Saavedra (2017), more than $70 \%$ of customer purchase decisions are made where the products or services are located, for them, strategies can be implemented at these points such as sales promoters, special decorations, banners, posters. discount, catalogs among others.

\subsubsection{Store atmosphere}

One of the purposes of Visual Merchandising is to make the consumer feel comfortable in the establishment and in this way ensure that they stay for longer than planned, raising the odds in their purchase decision. According to Gianella (2013), there are environmental factors that determine the atmosphere of the store. The first is lighting (light), which is a useful tool to appreciate the environment of the premises, since it must allow perceiving the product in detail, facilitating orientation in the store. According to Gianella (2013) the lighting distribution can be: (a) general with supplementary lighting, apart from a uniform light system, there are other systems that help to highlight one or more products; (b) general, which provides an optimal and uniform level of illumination; (c) general located, it is located in specific places of the store without generating chiaroscuro. Another factor is the decoration and aroma of the premises, such as the combination of colors or seasonal themes that attract customers. Smell is a sense that is related to memory and emotions, it identifies aromas in the environment and sends them to the brain, for this reason, companies use this type of aromatic marketing strategy more frequently in order to build loyalty to his clients. 
Music is a factor that also influences people's emotions, and depending on the type it will help the consumer to decide on their purchase, for this reason, relaxing music will help prolong the consumer's time in the store, a fast music will favor a faster circulation in the business, instrumental music will help to promote sales, however, well-known music tends to distract the consumer, consequently, it will decrease sales.

\subsection{Purchase decision}

The purchase decision refers to the act of choosing between two or more courses of action. However, it must be remembered that there cannot always be a correct decision among the available options. It is possible that there was a better option that was not considered, or that the right to information was not available at that time. Because of this, it is important to keep track of important decisions and the reasons for the decision made, for future improvements. This also provides a justification for any decision made when something is not in your favor. Hindsight may not be able to correct past mistakes, but it will help improve the purchase decision in the future. When buying a product or requesting a service, this is not a simple or spontaneous act as it may seem. The purchase decision will depend on multiple factors, and after all these factors have influenced the consumer's mind, the consumer will decide to buy or not to buy. If the option is to buy, consecutively it attracts another series of questions, such as where and when to make the purchase, how to receive the order, how much to spend, etc. So, it is understood that the purchase decision responds to the start of another series of decisions. All the responses and choices that the consumer will make will be based on their needs and preferences, and if this were not the case, the merchant will be able to influence this by practicing different strategies that make the consumer want to purchase one or another product more than it requires (Cotrina, 2018). Botero et al. (2005) point out that consumer behavior began to be studied in the 1950s, when Sigmund Freud spoke of the emotional reasons that could influence an individual's purchase decision; as it also highlights that the Ford Foundation in the United States, created a two-year study to increase and improve the level of research in the country's business schools. Normally, decisions can be made using intuition or reasoning; a combination of both approaches is often used. The consumer goes through several steps in the purchase decision process. For the first step, the decision is made to solve any type of problem. For this, the search for information on the product is carried out, for example, to find out how to prepare some type of food, using potatoes or substituting sweet potatoes or cassava. This leads to the evaluation of alternatives and a cost-benefit analysis that is largely done to judge which product and brand image will be suitable, and can adequately and adequately solve the problem. Thereafter, the purchase is finally made and the product is used by the consumer. Constant use of the product leads to consumer satisfaction or dissatisfaction, which leads to repeat purchases or rejection of the product (Pólya, 2012).

Kotler and Armstrong (2017) mention that consumer purchasing decisions are in most cases influenced by their cultural, social, personal and psychological characteristics; cases in which the marketers cannot have control, but they must take them into account for the strategies they may propose. This mentions 4 factors: (a) cultural, factors that can greatly influence the consumer's purchase decision; taking into account their culture, subculture and social class; (b) social, made up of groups and social networks, family, roles and status; (c) personal, which refers to the age and stage of the life cycle, occupation, economic situation, lifestyle, personality and self-concept; and (d) psychological, made up of motivation, perception, learning, beliefs and attitudes. Santesmases (1996) defines consumer behavior as the set of activities carried out by an individual, from when the need arises until the purchase is made and subsequently used. It also includes the analysis of all the factors that have influenced the activities carried out. The behavior of the final consumer includes the following aspects: (a) the behavior of individual or group purchase or acquisition, for own consumption or that of third parties, with which it is related by family, friendship or affective ties; It includes all the activities carried out to obtain a good or service, including the payment thereof; (b) the behavior of final use or consumption of the goods and services purchased by oneself or by third parties; (c) the internal and external factors to the individual that influence the purchase process and the use or consumption of the purchased product.

\section{Research Model and Hypotheses}

Visual merchandising was considered as an independent variable, with the following constructs and indicators:

a) Outside business organization (OBA): label (M1, M2), showcase (M3, M4) and entrance (M5, M6).

b) Organization of the interior of the business (OBI): access points (M7, M8), location of the hot or cold zone (M9, M10), distribution of sections and products (M11, M12, M13), and points of sale (M17, M18).

c) Business environmental factors (EFB): lighting (M19), decoration and aroma (M20, M21), and music (M22).

The dependent variables are based on the theory of cultural, social, personal and psychological criteria of the Purchase Decision with the following constructs and indicators:

a) Purchase decision cultural criteria (CCPD), considered: culture (DC1), subculture (DC2) and social class (DC3).

b) Purchase decision social criteria (SCPD) were considered: reference groups (DC4), family (DC5), roles (roles) and status (DC6).

c) Personal purchase decision criteria (PeCPD) were considered: age and stage of the life cycle (DC7), occupation (DC8), economic situation (DC9), lifestyle (DC10) and personality (DC11).

d) Psychological purchase decision criteria (PsCPD) were considered: motivation (DC12), perception (DC13), learning (DC14), as well as beliefs and attitudes (DC15). 
From which the following conceptual model and hypotheses are established.

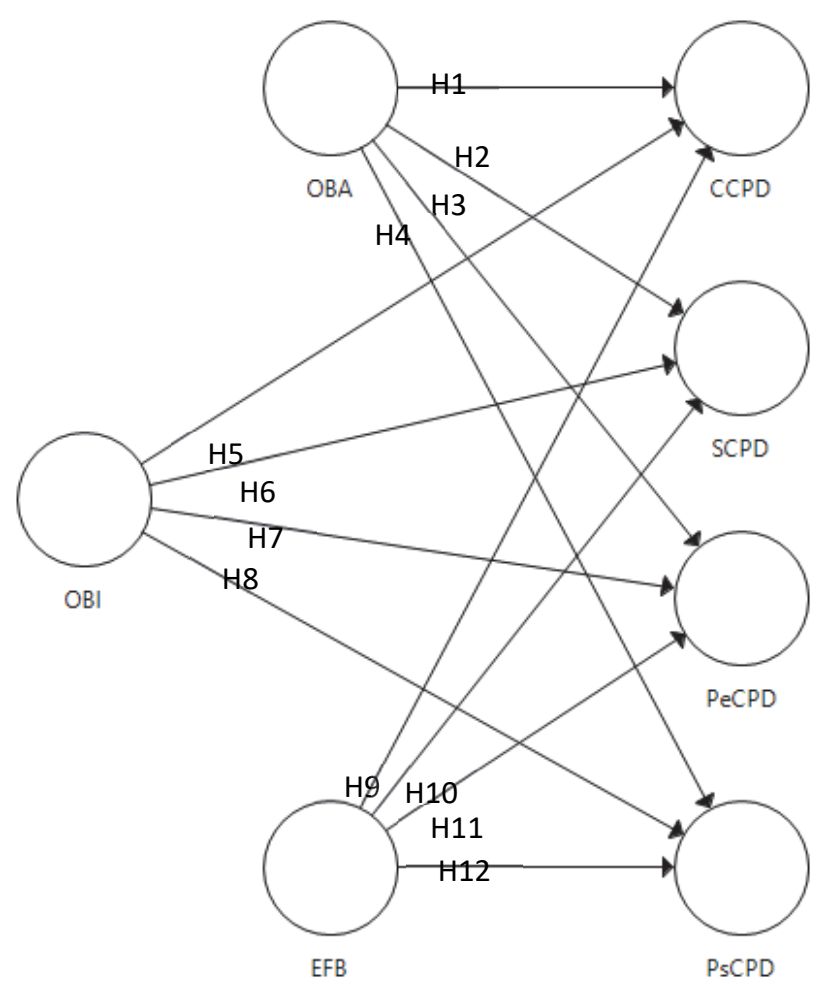

Fig. 1. Conceptual model and hypotheses

H1: The organization of the exterior of the business (OBA) generates a positive impact on the cultural criteria of purchase decision (CFPD).

$\mathrm{H} 2$ : The organization of the exterior of the business (OBA) generates a positive impact on the social criteria of purchase decision (CSPD).

H3: The organization of the exterior of the business (OBA) generates a positive impact on personal purchase decision criteria (CPePD).

H4: The organization of the exterior of the business (OBA) generates a positive impact on the psychological criteria of purchase decision (CPsPD).

H5: The organization of the interior of the business (OBI) generates a positive impact on the cultural criteria of purchase decision (CFPD).

H6: The organization of the interior of the business (OBI) generates a positive impact on the social criteria of purchase decision (CSPD).

$\mathrm{H7}$ : The organization of the interior of the business (OBI) generates a positive impact on personal purchase decision criteria (CPePD).

H8: The organization of the interior of the business (OBI) generates a positive impact on the psychological criteria of purchase decision (CPsPD).

H9: The environmental factors of the business (EFB) generate a positive impact on the cultural criteria of purchase decision (CFPD).

H10: The environmental factors of the business (EFB) generate a positive impact on the social criteria of purchase decision (CSPD).

H11: Environmental business factors (EFB) generate a positive impact on personal purchase decision criteria (CPePD).

H12: The environmental factors of the business (EFB) generate a positive impact on the psychological criteria of purchase decision (CPsPD).

\section{Method}

A correlational cross-sectional deductive study was conducted between the third quarter of 2019. 


\subsection{Population and sample}

The study population was made up of the inhabitants of the district of El Tambo and Huancayo, men and women in the age range of 20 and 60 years, and who are in the Mantaro Valley population of 159,197 inhabitants, according to the last census carried out by the National Institute of Statistics and Informatics (INEI, 2017). The districts with the highest percentage of population in this valley are El Tambo with 58\% and Huancayo with $42 \%$. In this context, the sample size (384 consumers or clients of the wineries) was obtained with an allowable margin of error of $5 \%$, a factor "p" of 0.5 and "q" of 0.5 , confidence level of $95 \%$.

\subsection{Data collection instrument}

Two questionnaires corresponding to each variable (visual merchandising and purchase decision) were developed based on 22 and 16 questions respectively. For the Visual Merchandising variable (6 for exterior architecture, 11 for interior architecture and 5 for atmosphere) and for the Purchase Decision variable ( 3 for cultural factors, 3 for social factors, 5 for personal factors and 5 for psychological factors). The instruments were validated by the judgment of four experts, who evaluated the instruments giving an average validity of $90 \%$. Likewise, reliability was estimated with the Cronbach's Alpha statistic, yielding a value of 0.89 and 0.87 for the Visual Merchandising and purchase decision instruments, respectively. The reliability results indicated that the instrument was reliable and suitable for its application. The research has high credibility since the results were obtained based on information production techniques. Likewise, the investigation complies with the standards to avoid plagiarism from other sources, guaranteeing the originality of the document.

\section{Results}

\subsection{Assessment of the Measurement Model}

Table 1 shows the measurement analysis of the model based on the reliability and validity of the measurement scales. Regarding reliability, the internal consistency of the scales is evidenced through the Cronbach Alpha value (between 0.720 to 0.861 ) and the composite reliability (between 0.797 to 0.915 ). Regarding convergent validity, all factor loads are above 0.700 . Likewise, all the scales have percentages of average variance extracted (AVE) greater than $50 \%$. The discriminant validity of the construct was tested by Fornell Larcker criteria, which verifies the independence of each of the scales, considering that the square root of the AVE is greater than the correlations with the rest of the scales. In all cases, the assumption was fulfilled.

Table 1

Results of the model measurement analysis

\begin{tabular}{|c|c|c|c|c|c|}
\hline Variables & Cronbach alpha & Composite reliability & $\begin{array}{l}\text { Factor loads } \\
\text { (range) }\end{array}$ & $\begin{array}{c}\text { Average variance extracted } \\
\text { (AVE) }\end{array}$ & Discriminant Validity \\
\hline CCPD & 0.769 & 0.865 & $0.768-0.867$ & 0.682 & 0.826 \\
\hline EFB & 0.783 & 0.860 & $0.711-0.827$ & 0.607 & 0.779 \\
\hline OBA & 0.836 & 0.879 & $0.647-0.820$ & 0.550 & 0.741 \\
\hline OBI & 0.874 & 0.900 & $0.606-0.831$ & 0.503 & 0.709 \\
\hline PeCPD & 0.857 & 0.896 & $0.767-0.818$ & 0.633 & 0.795 \\
\hline PsCPD & 0.895 & 0.927 & $0.842-0.900$ & 0.759 & 0.871 \\
\hline SCPD & 0.794 & 0.879 & $0.828-0.856$ & 0.708 & 0.842 \\
\hline
\end{tabular}

As shown in Fig. 2, an R2 of 0.102 was obtained on average, which determines a value greater than 0.100 , which is very significant, showing that the model significantly explains the variance of the dependent variables.

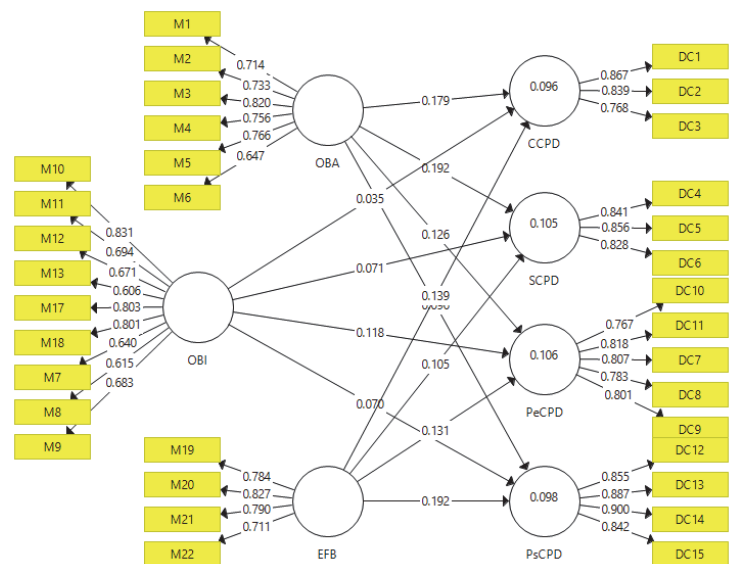

Fig. 2. Results for the hypothesized model with structural equations

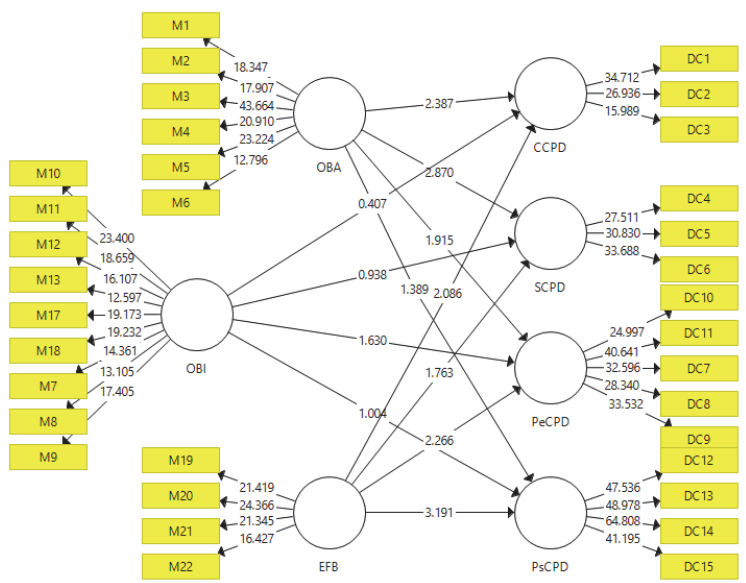

Fig. 3. Visual merchandising modeling in the purchase decision 


\subsection{Assessment of the Structural Model}

After verifying the validity and reliability of the measurement model, the relationships of the constructs were tested. The hypotheses were tested by examining the road coefficients and their significance levels. Bootstrapping was performed with 5000 subsamples to verify the statistical significance of each of the road coefficients. Figure 3 shows the estimated trajectory of the PLS analysis. Considering that 5 specific relationships have $\mathrm{p}<0.05$, the hypotheses proposed H1, H2, H9, H11 and H12 are accepted as shown in Table 2.

Table 2

Results of the model structure analysis

\begin{tabular}{|c|c|c|c|c|c|}
\hline Hypotheses & Mean sample & Standard deviation & Beta & $\mathrm{p}$ value & Decision \\
\hline $\mathrm{OBA} \rightarrow \mathrm{CCPD}$ & 0.181 & 0.075 & 2.387 & 0.017 & Accept H1 \\
\hline $\mathrm{OBA} \rightarrow \mathrm{SCPD}$ & 0.195 & 0.067 & 2.870 & 0.004 & Accept H2 \\
\hline $\mathrm{OBA} \rightarrow \mathrm{PeCPD}$ & 0.128 & 0.066 & 1.915 & 0.056 & Denies H3 \\
\hline $\mathrm{OBA} \rightarrow \mathrm{PsCPD}$ & 0.097 & 0.069 & 1.389 & 0.165 & Denies H4 \\
\hline $\mathrm{OBI} \rightarrow \mathrm{CCPD}$ & 0.041 & 0.085 & 0.407 & 0.684 & Denies H5 \\
\hline $\mathrm{OBI} \rightarrow \mathrm{SCPD}$ & 0.078 & 0.076 & 0.938 & 0.348 & Denies H6 \\
\hline $\mathrm{OBI} \rightarrow \mathrm{PeCPD}$ & 0.126 & 0.072 & 1.630 & 0.103 & Denies H7 \\
\hline $\mathrm{OBI} \rightarrow \mathrm{PsCPD}$ & 0.076 & 0.070 & 1.004 & 0.315 & Denies H8 \\
\hline $\mathrm{EFB} \rightarrow \mathrm{CCPD}$ & 0.139 & 0.067 & 2.086 & 0.037 & Accept H9 \\
\hline $\mathrm{EFB} \rightarrow \mathrm{SCPD}$ & 0.105 & 0.059 & 1.763 & 0.078 & Denies H10 \\
\hline $\mathrm{EFB} \rightarrow \mathrm{PeCPD}$ & 0.131 & 0.058 & 2.266 & 0.024 & Accept H11 \\
\hline $\mathrm{EFB} \rightarrow$ PsCPD & 0.192 & 0.060 & 3.191 & 0.001 & Accept H12 \\
\hline
\end{tabular}

\section{Discussion and conclusion}

\subsection{Regarding the impact of the organization from outside the business $(O B A)$ in the purchase decision}

The organization of the business outside has a significant influence on the cultural $(p<0.05)$ and social $(p<0.05)$ criteria of the purchase decision; and a negative relationship with personal $(p>0.05)$ and psychological factors $(p>0.05)$. This is in line with Shankhwar (2017), who notes that retailers use Visual Merchandising to differentiate their offerings from others, as well as to improve the convenience of products. Likewise, Ramírez and Alférez (2014) established that Visual Merchandising has a direct impact on the purchase decision of clients in their studio. Similarly, Randhawa and Saluja (2017) found that visual merchandising impacts the impulse to purchase, since consumers through their behavior provide information on their preferences, and in the case of retailers, special care must be taken to display their merchandise effectively using various marketing techniques. Also, it is in accordance with what was found by Cotrina (2018), who in his study for the Lima international fair, concluded on the existence of a correlative link between the purchase decision and Visual Merchandising. For their part, Duran and Nieto (2014) stated that people perceive innovation in products through Visual Merchandising, which positively influences when choosing and buying a product. This attraction is explained by Buitrago and Perea (2015), who mention that the purchase is explained, since customers are attracted in a rational and emotional way, achieving a satisfactory shopping experience.

\subsection{Regarding the impact of the organization of the interior of the business (OBI) in the purchase decision}

The organization of the interior of the business (OBI) does not have a positive relationship with the purchase decision of the consumers of the surveyed retail stores ( $>0.05$ for H5, H6, H7 and H8). This is due to the limited knowledge they have regarding the organization of the product at the point of sale. This is consistent with what Bhatti and Latif (2014) mention, who found that factors such as forum display and window display are negatively related to the consumer's purchase decision; however, the merchandising of the flat and the store's brand name are positively related to consumer purchasing behavior. Likewise, Sierra (2016) mentions that the interior environment of an establishment must act together, in order to provide the consumer with a pleasant and memorable experience. This can therefore translate into a positive purchasing decision.

\subsection{Regarding the impact of environmental business factors (EFB) on the purchase decision}

The environmental factors of the business (EFB) generate a positive impact on the cultural criteria $(p<0.05)$ of the purchase decision (CFPD), which indicates through the questionnaires that the familiarity of the place, the advertising of the products and the Brands of the exhibited products are directly related to the purchase decision of consumers. However, the environmental factors of the business do not generate a positive impact on the social criteria $(p>0.05)$ of the purchase decision (CSPD), which indicates that the reference of acquaintances, opinion of the family and the variety of products tend to have a lower percentage of importance when deciding on the purchase, on the other hand, the environmental factors of the business do generate a positive impact on personal criteria $(p<0.05)$ of purchase decision $(C P e P D)$, which indicates in In this case, the hours of operation, the proximity of the place, prices and the type of products they offer if they are directly related to consumers for the purchase decision. Finally, the environmental factors of the business generate a positive impact on the psychological criteria $(p<0.05)$ of the purchase decision $(\mathrm{CPePD})$, that is, a pleasant environment, positioning of the winery, positive experiences prior to the purchase and the quality of the Products are of utmost importance to consumers when deciding on purchase, which is directly related. For his part, Flores (2017), indicated that, in the purchase decision, customer service, product presentation, and product quality have significant influence. To this is added what was found by Reyes and Neyra 
(2013), who mentioned that the commercial identification, the white label and the different displays used represent the most relevant factors. In this sense, the results indicate that the purchase decision is influenced by the practice of different strategies that make the consumer want to purchase one or another product more than what is required (Cotrina, 2018). In addition to this, the constant use of the product leads to consumer satisfaction or dissatisfaction, which leads to repeat purchases or rejection of the product (Pólya, 2012). On the other hand, it is recommended that retail stores should employ adequate techniques in terms of lighting, decoration, local music, and aroma; in such a way that customers feel comfortable when entering the premises and perceive it as a pleasant place where they can shop safely and with a good atmosphere. Regarding the factors of visual merchandising, the three analyzed in the research external business organization (exterior architecture), internal business organization (interior architecture) and atmosphere, were found to explain the purchase decision. This is in accordance with what is proposed by Palomares (2015), who dimensioned Visual Merchandising in the factors indicated.

\section{References}

Bhatti, K. \& Latif, S. (2014). El impacto del merchandising visual sobre el comportamiento impulsivo de compra de los consumidores. Eurasian Journal of Business and Management, 2(1), 25-35.

Botero, M., Abello, L., Chamorro, M. \& Torres, V. (2005). Factores compensatorios y no compensatorios que influyen en la decisión de compra de productos culinarios en la categoría de caldos concentrados, en consumidores de la ciudad de Barranquilla. Universitas Psychologica, 4(3), 393-402.

Buitrago, R. \& Perea, J. (2015). La gerencia, el neuromarketing y el merchandising de retail de bajo presupuesto un nuevo modelo para aplicar en pequeñas y medianas superficies (tesis de pregrado). Universidad ECCI, Bogotá, Colombia.

Castillo, S. (2019). El Visual Merchandising está cambiando constantemente, tan rápido como el consumidor. Mercado negro. Recuperado de https://www.mercadonegro.pe/retail/castillo-el-visual-merchandising-esta-cambiando-constantementetan-rapido-como-el-consumidor/

Cotrina, C. (2018). Merchandising en la decisión de compra de los consumidores de la feria iternacional Lima de la ciudad de Tacna 2017 (tesis de maestría). Universidad Privada de Tacna, Perú.

Duran, A. \& Nieto, M. (2014). El merchandising visual como estrategia decisiva en las tiendas de Zara, Pilatos, Studio F en la ciudad de Cali de los centros comerciales Jardin Plaza y Chipichape y el impacto en las compras del consumidor (tesis de pregrado). Universidad Autónoma de Occidente, Santiago de Cali, Colombia.

Flores, R. (2017). Influencia del merchandising visual en el comportamiento de compra del consumidor en la Empresa Andeanvet SAC, distrito Lince 2016 (tesis de pregrado). Universidad César Vallejo, Lima, Perú.

Gianella, A. (2013). Visualmin marketing o amor a primera vista. Bogotá, Colombia: Ediciones de la U.

Instituto Nacional de Estadística e informática (INEI) (2017). Estadísticas municipales 2016. Recuperado de https://www.inei.gob.pe/media/MenuRecursivo/publicaciones_digitales/Est/Lib1417/libro.pdf

Kotler, P. \& Armstrong, G. (2017). Fundamentos de marketing. México: Pearson prentice hall.

Miquel, S., Parra, F., Lhermie, C. \& Miquel, J. (2008). Distribución comercial. Madrid, España: ESIC Editorial.

Palomares, R. (2011). Merchandising: Teoría, práctica y estrategia. Madrid, España: ESIC Editorial.

Palomares, R. (2015). Merchandising: En Auditoría de marketing en el punto de venta. Madrid, España: ESIC Editorial.

Pólya, É. (2012). Purchase decision making processes and roles within the family (tesis doctoral). Szent István University, Hungría.

Ramírez, C. \& Alférez, L. (2014). Modelo conceptual para determinar el impacto del merchandising visual en la toma de decisiones de compra en el punto de venta. Pensamiento y gestión, 36(1), 1-27.

Randhawa, K. \& Saluja, R. (2017). ¿El merchandising visualtiene un efecto en el comportamiento de compra impulsado por el consumidor? Revista de investigación general de gestión, 4(2), 58-71.

Reyes, Y., \& Neyra, E. (2013). Merchandising y decisión de compra en el punto de venta del Fast Food Piccolo de la ciudad de Huaraz. 2013 (tesis de pregrado). Universidad Nacional Santiago Antúnez De Mayolo, Huaraz, Perú.

Saavedra, K. (2017). El merchandising visual y su influencia en el comportamiento del consumidor de una tienda retail de artículos de electrónica menor en el C.C. Real Plaza de la ciudad de Trujillo en el año 2017(tesis de pregrado). Universidad Privada del Norte, Trujillo, Perú.

Salazar, F. (2016, 27 de mayo). La segmentación de las bodegas en América Latina, Perú. Conexiónesan. Recuperado de https://www.esan.edu.pe/conexion/actualidad/2016/05/27/la-segmentacion-de-las-bodegas-en-america-latina/

Santesmases, M. (1996). Marketing: Conceptos y estrategias. Madrid, España: Pirámide.

Shankhwar, K. (2017). Influence of Visual Merchandising on Buying Behavior of Consumers in Gwalior. IJARIIE, 3(2), 23954396.

Sierra, A. (2016). Visual Merchandising y Tecnología. Seducir al shopper en el punto de venta. Madris, España: ESIC Editorial.

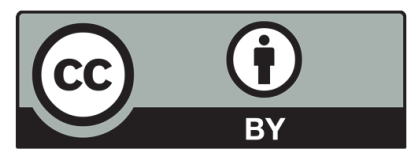

(C) 2020 by the authors; licensee Growing Science, Canada. This is an open access article distributed under the terms and conditions of the Creative Commons Attribution (CC-BY) license (http://creativecommons.org/licenses/by/4.0/). 